\title{
Leadership 101 \\ Column 2: Leadership versus management - Either, or, both?
}

\section{Laurie Scott}

This series of columns addressing the topic of leadership is based on the Canadian Health Libraries Association / Association des bibliothèques de la santé du Canada (CHLA / $A B S C$ ) accredited course "Discover the Leader in You: Developing and Realizing your Leadership Potential", developed and delivered by D. Phelan, L. Scott, and W. Glover. Interested readers are encouraged to join the CHLA / ABSC Leadership Interest Group (http://www.chlaabsc.cal?q=en/node/217).

For many people, leadership is frequently associated with management or administration. Indeed, as noted in a previous column, Library Literature indexes articles dealing with leadership using subject headings for administration. It is possible to be a competent manager without being a strong leader, and vice versa. Some individuals are able to combine leadership abilities with strong administrative skills. We are fortunate indeed when we are able to work with individuals who have these qualities. More frequently, however, individuals will have strengths in one or the other camp.

Effective managers and administrators have strong organizational, time management, interpersonal, and financial skills. They may or may not supervise staff. They are adept at overseeing often complex and detailed tasks. One of the pioneers of the study of leadership, Warren Bennis, summarized his view of the difference between leaders and managers/administrators through a list of contrasting qualities and functions:

- The manager administers; the leader innovates.

- The manager is a copy; the leader is an original.

- The manager maintains; the leader develops.

- The manager focuses on systems and structure; the leader focuses on people.

- The manager relies on control; the leader inspires trust.

- The manager has a short-range view; the leader has a long-range perspective.

- The manager asks how and when; the leader asks what and why.

- The manager has his eye on the bottom line; the leader has his eye on the horizon.
- The manager imitates; the leader originates.

- The manager accepts the status quo; the leader challenges it.

- The manager is the classic good soldier; the leader is his own person.

- The manager does things right; the leader does the right thing. 1

Bennis is, perhaps, a bit hard on managers. Not all managers have leadership potential, nor do all management positions require incumbents to lead. A good administrator is worthy of respect, and there is a strong role for such individuals in every organization.

So what, then, of leadership? Just as managers are not necessarily leaders, so too, leaders may not be effective managers. Consider the concept of a charismatic leader who can inspire people yet can't get to a meeting on time or balance the books! Leaders are focused on the big picture and may get bogged down when faced with details.

It is important to note that leaders are not necessarily in positions of authority. It is possible to lead "from the ranks"-to inspire people and influence policy without it being part of one's job description. Librarians in junior positions are often the people who come up with the most innovative ideas. Those junior librarians who have leadership qualities can make their case and carry their ideas to fruition, to the benefit of the whole organization. Stoyko et al. call this concept of leading without authority being an "idea leader":

Building creative organizations requires leadership. Leadership can be exercised at any level within an organization. An idea leader is someone who knows how to spot a good idea and adapt it to suit the organization's needs...An idea leader is also someone who is conscious of how personal actions can inadvertently affect fledgling ideas. Creativity is often destroyed by the actions of managers who are focusing on other things. ${ }^{2}$

One leadership quality that often comes to the fore in any discussion of how leaders differ from managers (or any nonleader) is charisma. One might suggest that an administrator is unlikely to be charismatic, while it would be absolutely

\footnotetext{
${ }^{1}$ W. Bennis. Managing the dream: Leadership in the 21st century. The Antioch Review. 1991 Winter;49(1):22.

${ }^{2}$ P. Stoyko, G.K. Henning, D. McCaughey. Creativity at work: a leadership guide. CSPS Action-Research Roundtable on Creativity. Ottawa: Canada School of Public Service; 2006 [retrieved 2008 Jun 23]. Available from: http://dsp-psd.pwgsc.gc.ca/collection_2008/cspsefpc/SC103-23-2006E.pdf.
} 
essential for a leader to have that quality. There can be little doubt of the fact that charisma will carry an individual a long way, regardless of whether there is substance below the surface. The late leadership guru Peter Drucker, in one of his final interviews, addressed the issue of charismatic leadership:

You know, I was the first one to talk about leadership 50 years ago, but there is too much talk, too much emphasis on it today and not enough on effectiveness. The only thing you can say about a leader is that a leader is somebody who has followers. The most charismatic leaders of the last century were called Hitler, Stalin, Mao, and Mussolini. They were mis-leaders! Charismatic leadership by itself certainly is greatly overstated. Look, one of the most effective American presidents of the last 100 years was Harry Truman. He didn't have an ounce of charisma. Truman was as bland as a dead mackerel. Everybody who worked for him worshiped him because he was absolutely trustworthy. If Truman said no, it was no, and if he said yes, it was yes. And he didn't say no to one person and yes to the next one on the same issue. ${ }^{3}$

So, charisma is not a "must have" when it comes to being a leader, although it can be an asset to a good leader. Drucker makes an excellent point in highlighting the destructive potential of charisma in a person who would "lead" others in evil or, in less dramatic contexts, ill-conceived causes. Perhaps a new term, "mis-leadership" should be created to apply to these individuals.
In the course, "Discover the Leader in You", case studies are used to examine the differences between management and leadership. Consider the following example:

You are the head of a hospital library. The library advisory committee is meeting and discussing the allocation of budget resources on e-journals versus print journals. Two of the six committee members disagree strongly. One member feels the library should abandon print entirely, citing the desire of most users to access materials from outside the library and the need to free up space for other purposes. The other member is equally adamant that he needs paper copies of all the important journals both current subscriptions and back runs for both clinical and research purposes. The meeting is getting bogged down in an endless debate between these two strongly opinionated people. You are not the chair of the advisory committee, and the chair seems unable to bring the discussion under control.

What action would you take to show leadership in resolving the dispute described? Do you think a manager would approach it differently? If so, in what ways? Something to ponder until the next issue!

\section{Laurie Scott}

Research and Education Services

Bracken Health Sciences Library

Queen's University

Kingston, ON K7L 3N6, Canada

E-mail: laurie.scott@queensu.ca

\footnotetext{
${ }^{3}$ R. Rich. Peter Drucker on Leadership. Forbes.com. 2004 November 19 [retrieved 2008 Jun 23]. Available from: http://www.forbes.com/ 2004/11/19/cz_rk_1119drucker.html.
} 